\title{
Firm Failure Prediction: The Financial Distress Model vs Traditional Models
}

\author{
Ivica Pervan ${ }^{1, *}$, Maja Pervan ${ }^{1}$ and Tamara Kuvek ${ }^{1}$ \\ ${ }^{1}$ Faculty of Economics, University of Split, Cvite Fiskovića 5, 21000 Split, Croatia \\ E-mail: \{\{pervan, mpervan\}@efst.hr, tamara.pds@gmail.com\}
}

\begin{abstract}
Modelling firm failure, classically defined as bankruptcy, is problematic in the Croatian business environment since the bankruptcy procedure starts at a very late stage of crisis, when a firm liabilities are higher than assets. In order to overcome this problem, we propose an alternative definition of firm failure which is based on a firm's financial status, meaning financial distress, rather than its legal status. A firm is characterised as financially distressed when its EBITDA is lower than its interest expenses for two consecutive periods. Accordingly, we developed models based on three different failed firm statuses: (i) bankruptcy, (ii) rescue plan and (iii) financial distress. The application of logistic regression on a sample of Croatian firms has shown that a financial distress model has a high level of predictive power. Moreover, for the whole sample this model outperformed bankruptcy and rescue plan models in terms of overall accuracy and the prediction of failure status. Additional analysis has revealed that it is useful to develop a model for non-micro firms because such an estimation results in improved prediction power in comparison with a generic, one-size firm model. In the case of non-micro firms, the financial distress model outperformed the rescue plan model, while the hit rate was similar to the hit rate of the bankruptcy model. A developed financial distress model can be applied by investors and creditors in order to timely evaluate firm failure risks and undertake required business decisions.
\end{abstract}

Keywords: firm failure, financial distress, bankruptcy, rescue plan, Croatia

Received: August 13, 2018; accepted: October 22, 2018; available online: December 13, 2018

DOI: 10.17535 /crorr.2018.0021

\section{Introduction}

The issue of firm failure has become especially relevant after the global financial crisis started in 2007 and caused a global recession in the period of 2008-2012. Consequently, many firms struggled with plummeted demand and lower revenues, what in the short term resulted in illiquidity, while in the long term many of distressed firms ended up in bankruptcy. The last economic crisis had prolonged effects in Croatia and negative economic growth was present until the third quarter of 2014. A good indicator of failure risk in the Croatian business environment is the number of illiquid firms, i.e. firms with blocked accounts. In the peak of the economic crisis (in 2011), the number of illiquid firms was more than 85,000, while the latest available data from January 2018 reveals that the number of illiquid firms has fallen to 30,000 [12]. Insight

\footnotetext{
* Corresponding author.
} 
into the Amadeus database (July 2018) reveals that there were $3.7 \%$ legally failed (bankruptcy and rescue plan) firms among the total number of firms. The EU average was $1.3 \%$, which leads to the conclusion that the Croatian business environment is three times riskier in comparison with the EU average.

The traditional approach in the prediction of firm failure is often based on the legal definition of firm failure. Authors often only treat those firms which have entered into bankruptcy or a similar court oversight procedure as having failed. Although this approach to firm failure modelling can be useful for developed countries with a high level of law enforcement, this is often not the case for emerging countries such as Croatia. Namely, bankruptcy procedures are often started too late, i.e. when a firm's liabilities are higher than its assets. Such a standpoint is clearly supported by recent data (July 2018) from the Amadeus database, which reveals that on average Croatian bankrupt firms' equity becomes negative four years before bankruptcy. As a consequence, creditors can recover only a small portion of receivables. Only modelling bankruptcy would result in a model that predicts only the very late stage of firm crisis, which in Croatia often leaves no time for investors and creditors to undertake appropriate decisions. Therefore, the Croatian business environment requires the development of an early warning system, in which firm failure would be defined by a firm's financial condition, rather than by its legal status. This paper adds to the firm failure literature by developing a model in which firm failure is defined on the basis of a firm's financial health. No research has yet explored firm failure modelling in Croatia in this way. Moreover, this study is the first of its kind that has been carried out in one of the Central and Eastern European (CEE) countries and is among the few worldwide (Brazil, the US and G-7 countries).

In order to test the developed financial distress model, beside the traditional calculation of model prediction accuracy we have decided to compare the model with the traditional bankruptcy prediction model and the rescue plan model. Moreover, all three models have been tested with the use of accounting information one, two and three years before the particular firm failure status occurs. Such an approach allows us to evaluate the level of the deterioration of the usefulness of accounting information during this time. This issue is important in situations when recent accounting information is not available, which is a real-life situation in Croatia because many failed firms do not provide information for public use one year before legal failure. Empirical findings based on the application of logistic regression has revealed that the financial distress model resulted in a high level of predictive power and for the whole sample has outperformed traditional legal status models in terms of prediction accuracy. In the case of non-micro firms financial distress model outperformed rescue plan model, while the hit rate was similar to the hit rate of the bankruptcy model. Additional analysis regarding the a firm's size has resulted in finding that the estimation of a separated distress model for non-micro firms' yields a higher prediction power in comparison with a generic, one-size firm model.

The rest of the paper is organized as follows. A review of relevant studies on firm failure is presented in the second section. The third section deals with the sample description, variables and statistical methodology. Major empirical findings are presented in the fourth section, which is followed by concluding remarks.

\section{Literature review}

The statistical modelling of firm failure started with seminal papers by Beaver [8] and Altman [1], while an important shift in statistical methodology was offered by Ohlson [17], who suggested the use of a logit model since it is more robust in comparison with Multivariate Discriminant Analysis (MDA), and it is based on less restrictive requirements. Despite the existence of a large number of firm failure studies, there is no clear evidence on which statistical technique is best, and therefore there is no consensus on choice of methodology [6]. In order to evaluate the risk of firm failure, many failure studies focus on accounting information from financial statements and financial ratios. The root of this approach can be found in 
pioneering papers on failure prediction and it is often replicated in recent papers. Modern financial reporting frameworks (FASB and IASB) state that accounting information should be useful for investment and/or crediting decisions. A review of failure literature leads to the general conclusion that accounting information can be effectively used for firm failure prediction.

Although many papers fall into the general category of firm failure research, the definition of a failure variable differs among studies. Many papers only consider firms which have started the bankruptcy procedure as failed ones [1], [10], [17], [16], [9], etc. Beaver [8] defines failure more comprehensively and his approach includes bankruptcy, bond default, overdrawn bank accounts and the nonpayment of preferred dividends. Some papers use multiple criteria when defining failure, usually combining bankruptcy with some other criteria such as receivership/liquidation [4], default on loans/reorganizing debt [27], negative equity [29], and liquidation/negative equity [26].

An additional approach in defining firm failure can be illiquidity status [15], [19] and [25]. Illiquidity represents a situation in which, at some point in time, a firm is unable to settle due liabilities and therefore its account is blocked. Illiquidity usually can be perceived as an early stage of firm financial distress and if it continues for a period longer than 90 days, banks often classify such clients as defaulted. Only a few academic papers [2], [18] employ the firm default status, probably due to the fact that default information is not publicly available.

The use of bankruptcy as a dependent variable in academic papers is popular since bankruptcy status can be easily identified from different databases. However, Balcaen and Ooeghe [6] put into question the use of legal bankruptcy as only failure status since bankruptcy timing may be much latter than the real moment of firm failure. In emerging economies such as Croatia, it is not unusual that law enforcement is problematic and financially distressed firms often enter into bankruptcy procedures at a very late phase of a crisis. Such a legal environment is not very protective from the perspective of creditors since bankruptcy often results in firm liquidation because liabilities exceed assets, i.e. distressed firms enter into bankruptcy with negative equity.

According to the latest data from the World Bank Group Doing Business project (http://www.doingbusiness.org/), creditors in Croatia can recover only $32.7 \%$ of receivables from insolvency procedures. In other comparable CEE countries the receivables recovery rate is significantly higher (Slovenia 88.7\%, Czech Republic 67\%, Hungary 43\%). In Croatia many insolvent firms continue to operate and according to Sajter [23], only 5\% of insolvent firms enter into bankruptcy procedures, while 95\% are tolerated to continue operations.

All previously described arguments call for the development of an early warning system, which would be able to indicate the probability of firm failure early enough that investors and creditors would have enough time to undertake the appropriate decisions. For the purpose of early warning model development, financial distress should reflect the financial health status that precedes bankruptcy. A surprisingly limited number of academic papers have dealt with this issue and there is no unique definition of financial distress status. Platt \& Platt [21] analyzed financial distress among automotive suppliers and searched for failed firms that had negative EBIT for several years, suspended dividends payments and undertook major restructurings, or layoffs. Pindado et al. [20] and Rezende et al. [22] defined a firm as financially distressed when its EBITDA was lower than interest expenses for two consecutive periods and its market value was in decline for two consecutive periods.

\section{Data, variables and research methodology}

All data required for the development of failure models was retrieved from the BvD Amadeus database in June 2018. The data available in Amadeus provided us with bankruptcy status information for the years 2016 and 2017. Among active firms, we were especially interested to identify firms that entered into "rescue 
plan" status. Rescue plan information for Croatian firms was available for the period from 2013 to 2017. Financial distress status was defined for the years 2016 and 2017 on the basis of its EBITDA and the financial expenses of two preceding years. In line with the presented criteria, the total number of failed observations is given in Table 1 .

\begin{tabular}{|l|l|}
\hline Status & Number of observations \\
\hline Bankruptcy & 1,330 \\
\hline Rescue plan & 1,198 \\
\hline Financial distress & 4,618 \\
\hline
\end{tabular}

Table 1: Total number of observations by failure status

Insight into the obtained data has revealed that many of failed firms did not have accounting information for all three consecutive years as required by research design. At this stage of research, we could choose to delete all firms that did not meet this criteria. Indeed, such an approach would result in the same number of observations for each failure status in all three years, but at the same time this approach would generate survival and young firm biases. Hence, in order to avoid these biases we have decided to define a separated subsamples of failed firms for each year (one, two and three years before a particular failure status occurred) that was included in the analysis. We deleted failed firms from the sample only for the year in which its accounting data was missing. Such an approach of excluding missing data resulted in the number of failed observations presented in Table 2.

\begin{tabular}{|l|l|l|l|}
\hline Status & $\begin{array}{l}\text { One year before } \\
\text { failure (t-1) }\end{array}$ & $\begin{array}{l}\text { Two years before } \\
\text { failure }(\mathrm{t}-2)\end{array}$ & $\begin{array}{l}\text { Three years before } \\
\text { failure (t-3) }\end{array}$ \\
\hline Bankruptcy & 244 & 483 & 551 \\
\hline Rescue plan & 808 & 853 & 887 \\
\hline Financial distress & 3,200 & 3,242 & 3,033 \\
\hline
\end{tabular}

Table 2: Number of observations by failure status used in different time lags

In order to define a sample of healthy firms we applied the paired matching procedure, according to which for every failed firm the procedure generated one healthy firm. This approach included matching firms by size and industry. All healthy firms within one industry were first listed by asset size and then an application of a random selection procedure provided the sample of healthy firms. However, since the aim of the research was to develop three separated failure models for three periods of lagged accounting data ( $\mathrm{t}-1$, $\mathrm{t}-2$ and $\mathrm{t}-3)$, the previously described matching procedure was executed separately for each estimated model.

For each model created, a particular firm status was defined as a binary outcome dependent variable, coded "0" for a healthy firm, and "1" for a failed firm (see Table 3). The use of financial ratios to predict firm failure has a long tradition that can be traced in early papers of Beaver [8], Altman [1], as well as in many recent papers. Firm failure literature leads to the general conclusion that financial ratios can be effectively used for firm failure prediction. Therefore, in line with previous studies, different financial ratios covering major aspects of a firm's operations (profitability, activity, liquidity and solvency) were considered in this research. As a firm moves from its desired (healthy) status to financial distress and rescue plan status and then toward bankruptcy status, a firm's profit deteriorate, its liquidity and solvency worsen, and its activity decreases. Therefore, the lower the value of these indicators, the higher a firm's inability to meets its obligations and continue its business operations.

Aside from using accounting-based measures as predictor variables, this research also encompasses some non-financial variables to control for firm age, firm size and industry belongings. The theory is equivocal on the relationship between firm age and firm failure status. One stream of research suggests that 
parallel with ageing, firms become more efficient since they have had sufficient time to exploit the benefits of learning by doing and to increase their productivity [13], while another stream of research suggests that due to their bureaucratic ossification, which reduces organizational flexibility, older firms are not so agile and are unlikely to make rapid adjustments in changing their business environment. Consequently, younger as well as older firms can be faced with a higher probability of failure.

\begin{tabular}{|l|l|l|}
\hline Variable & Acronym & Calculation \\
\hline Dependent variables alternatives (i, ii, iii) & B & Binary variable (1- bankrupted firm; 0 - healthy firm) \\
\hline Bankruptcy status & RP & Binary variable (1- rescue plan firm; 0 - healthy firm) \\
\hline Rescue plan status & FD & $\begin{array}{l}\text { Binary variable (1- firm in financial distress; 0 - } \\
\text { healthy firm) }\end{array}$ \\
\hline Financial distress status & \multicolumn{2}{|l|}{} \\
\hline Independent variables (i, ii) & ROA & EBIT/Assets \\
\hline Financial variables & EBITM & EBIT/Turnover \\
\hline Return on Assets & ATURN & Assets/Turnover \\
\hline Operating Margin & CUR & Current Assets/Current Liabilities \\
\hline Assets Turnover & SOL & Equity/Assets \\
\hline Current Ratio & AGE & Number of years after incorporation \\
\hline Solvency & SIZE & Natural logarithm of Assets \\
\hline Non-financial variables & IND & $\begin{array}{l}\text { Industry belongings (1- firm belongs to a particular } \\
\text { industry, 0 - otherwise) }\end{array}$ \\
\hline Firm Age &
\end{tabular}

Table 3: Description of variables

Regarding firm size, the theory is again ambiguous. While some researchers argue that larger firms are more profitable due to scale economies [7], market power [5], favorable financing conditions, other research argues that an increase in size might have negative effects on profitability because of the increased transaction costs of planning, monitoring and negotiating [28]. Finally, from the viewpoint of industry effects, Mirzaei et al. [14] provided theoretical arguments regarding why the industry may play an important role in determining the probability of firm failure. However, the results of their analysis showed only a partial influence of industry characteristics on the probability of default. While Smith and Liou [24] showed that firm failure is influenced by the industry effect, Altman et al. [3] found a marginal influence of industry on financial distress prediction. The description and the manner in which the independent (financial and non-financial) variables are calculated is presented in Table 3, which also encompasses a specification of dependent variables, a brief explanation of which is given in the following paragraphs.

Bankruptcy status is relatively easy to define since it represents the situation in which a legal procedure has started and the trade court has appointed a new firm administrator. Rescue plan status was introduced into the Croatian judicial system in 2012 and this legal innovation aimed to provide another opportunity to distressed firms and their creditors to renegotiate debt settlement, debt write-offs, equity restructuring, change in ownership and change in management. In a situation in which the rescue plan is accepted by the majority of creditors, a distressed firm would avoid bankruptcy and continue with its restructured operations. The definition of financial distress is more complex than the definitions of bankruptcy and rescue plan since this failure status is not a legal status and it represents the financial situation of the firm. In order to define financial distress, we have decided to follow the approach of Pindado et al. [20] and Rezende et al. [22], who defined that a firm is in financial distress when its EBITDA 
is lower than its interest expenses for two consecutive periods. This represents a situation in which the firm is unable to generate enough cash flow from its operations to repay its financial obligations.

As regards the research methodology, we have applied logistic regression since this method has fewer assumptions in comparison with multiple discriminant analysis [11]. While logistic regression represents a very robust statistical method, it is sensitive to the problem of multicollinearity among independent variables. The application of the Pearson Correlation coefficients matrix ${ }^{1}$ showed no presence of multicollinearity in our research, since neither correlation coefficient was higher than 0.7 .

The evaluation of the accuracy of alternative failure models is based on model error. Model error occurs when an originally healthy firm is classified by a model as a failed firm, or vice versa. Overall model error measures the total classification error for all firms (failed and healthy), while Type I error measures the classification error of failed firms only. We have applied the z-test for two population proportions regarding the comparison of error differences obtained from alternative failure models.

\section{Results and discussion}

The models presented in table 4 are based on the legal definition of firm failure, it comprises both financial and non-financial variables, which explains the likelihood that a firm will enter into bankruptcy and begin a rescue plan procedure. The overall fit of estimated bankruptcy models is moderately high since the pseudo $\mathrm{R}^{2}$ measure, Nagelkerke $\mathrm{R}^{2}$, lies in the range between $0.537(\mathrm{t}-3)$ and $0.664(\mathrm{t}-2)$. Regarding the estimated model coefficients, it was confirmed that profitability (ROA) was statistically significantly related to the likelihood of bankruptcy (for all time lags), while its negative sign indicated that an increase in profitability reduces the likelihood of bankruptcy. The same conclusion can be drawn for variables of activity (ATURN) and solvency (SOL). Firm size had a negative sign in all three bankruptcy models, but it was significant in only two models ( $\mathrm{t}-1$ and $\mathrm{t}-2$ ) indicating that larger firms are less likely to end up in a bankruptcy procedure. Negative coefficients were obtained for AGE, but this variable was significant only in one model (t-3). Surprisingly, in the case of bankrupted firms, the liquidity measured by the current ratio (CUR) had a positive sign, meaning that an increase in liquidity was positively related to bankruptcy.

In order to test the robustness of estimated bankruptcy models, we have separated the total sample into two subsamples, micro firms (assets $<2$ mil. $€$ ) and non-micro firms (assets $\geq 2$ mil. $€$ ). Such an estimation $^{2}$ in the case of non-micro firms has resulted in the same findings for variables ROA, ATURN and SOL in all time lags. However, firm liquidity has changed the sign into a negative one (as expected) in all time lags, while it was significant for only the t-2 time lag. In this specification AGE was insignificant, while SIZE had a negative sign and was significant for only the t-2 time lag. Dummy variables for industries were not statistically significant and therefore are excluded from the models presented in Table 4.

The bankruptcy prediction model for whole sample had an overall prediction error of $20.7 \%$ for the t-1 lag, while the overall error was lowest for the $\mathrm{t}-2$ lag (14.4\%). Similar findings were observable for the most important Type I error (failed firm classified as healthy), where the error was $22.5 \%$ (t-1) and $17.6 \%$ $(t-2)$. The model estimation only for non-micro firms yielded even better prediction results since the overall error was only $5.4 \%$ for the $\mathrm{t}-1 \mathrm{lag}$ and $5.3 \%$ for the $\mathrm{t}-2$ lag. Type I error was significantly lower in comparison with whole sample and equalled $5.9 \%(\mathrm{t}-1)$ and $4.5 \%(\mathrm{t}-2)$.

\footnotetext{
${ }^{1}$ Due to space constrain, the results of the Pearson Correlation coefficients matrix are not presented here, however, they are available upon request.

${ }^{2}$ Due to the space constrain, models for non-micro firms are not presented here, however, they are available on request.
} 


\begin{tabular}{|c|c|c|c|c|c|c|}
\hline \multirow[t]{2}{*}{ Variable } & \multicolumn{3}{|c|}{ Bankruptcy models (all firm sizes) } & \multicolumn{3}{|c|}{ Rescue plan models (all firm sizes) } \\
\hline & Model $_{\mathrm{t}-1}$ & Model $_{\mathrm{t}-2}$ & Model $_{\mathrm{t}-3}$ & Model $_{\mathrm{t}-1}$ & Model $_{t-2}$ & Model $_{\mathrm{t}-3}$ \\
\hline ROA & $\begin{array}{l}-0.027^{* *} \\
(0.011)\end{array}$ & $\begin{array}{l}-0.048^{* * *} \\
(0.010)\end{array}$ & $\begin{array}{l}-0.023^{* * *} \\
(0.007)\end{array}$ & $\begin{array}{l}-0.073^{* * *} \\
(0.010)\end{array}$ & $\begin{array}{l}-0.041^{* * *} \\
(0.007)\end{array}$ & $\begin{array}{l}-0.029^{* * *} \\
(0.007)\end{array}$ \\
\hline EBITM & $\begin{array}{l}0.001 \\
(0.006)\end{array}$ & $\begin{array}{l}-0.002 \\
(0.006)\end{array}$ & $\begin{array}{l}-0.002 \\
(0.005)\end{array}$ & $\begin{array}{l}-0.004 \\
(0.007)\end{array}$ & $\begin{array}{l}-0.009 \\
(0.005)\end{array}$ & $\begin{array}{l}-0.006 \\
(0.005)\end{array}$ \\
\hline ATURN & $\begin{array}{l}-0.049^{* *} \\
(0.017)\end{array}$ & $\begin{array}{l}-0.082^{* * *} \\
(0.019)\end{array}$ & $\begin{array}{l}-0.017^{* *} \\
(0.007)\end{array}$ & $\begin{array}{l}-0.034^{* * *} \\
(0.008)\end{array}$ & $\begin{array}{l}-0.059^{* * *} \\
(0.014)\end{array}$ & $\begin{array}{l}-0.046^{\text {*** }} \\
(0.012)\end{array}$ \\
\hline CUR & $\begin{array}{l}0.024 \\
(0.024)\end{array}$ & $\begin{array}{l}0.040^{* *} \\
(0.013)\end{array}$ & $\begin{array}{l}0.036^{* *} \\
(0.014)\end{array}$ & $\begin{array}{l}-0.230^{* * *} \\
(0.067)\end{array}$ & $\begin{array}{l}-0.064^{* *} \\
(0.024)\end{array}$ & $\begin{array}{l}-0.057 \\
(0.032)\end{array}$ \\
\hline SOL & $\begin{array}{l}-0.058^{* * *} \\
(0.006)\end{array}$ & $\begin{array}{l}-0.073^{* * *} \\
(0.005)\end{array}$ & $\begin{array}{l}-0.057^{* * *} \\
(0.004)\end{array}$ & $\begin{array}{l}-0.068^{* * *} \\
(0.005)\end{array}$ & $\begin{array}{l}-0.076^{* * *} \\
(0.004)\end{array}$ & $\begin{array}{l}-0.066^{* * * *} \\
(0.004)\end{array}$ \\
\hline AGE & $\begin{array}{l}-0.025 \\
(0.016)\end{array}$ & $\begin{array}{l}-0.015 \\
(0.012)\end{array}$ & $\begin{array}{l}-0.033^{* *} \\
(0.011)\end{array}$ & $\begin{array}{l}-0.032^{\text {*** }} \\
(0.008)\end{array}$ & $\begin{array}{l}-0.023^{* *} \\
(0.008)\end{array}$ & $\begin{array}{l}-0.026^{\text {*** }} \\
(0.007)\end{array}$ \\
\hline SIZE & $\begin{array}{l}-0.167^{* *} \\
(0.067)\end{array}$ & $\begin{array}{l}-0.176^{* *} \\
(0.057)\end{array}$ & $\begin{array}{l}-0.064 \\
(0.044)\end{array}$ & $\begin{array}{l}0.491^{* * *} \\
(0.046)\end{array}$ & $\begin{array}{l}0.449^{* * *} \\
(0.041)\end{array}$ & $\begin{array}{l}0.409^{* * *} \\
(0.039)\end{array}$ \\
\hline Constant & $\begin{array}{l}3.883^{* * *} \\
(0.504)\end{array}$ & $\begin{array}{l}4.143^{* * *} \\
(0.450)\end{array}$ & $\begin{array}{l}3.014^{* * *} \\
(0.334)\end{array}$ & $\begin{array}{l}0.979^{* * *} \\
(0.328)\end{array}$ & $\begin{array}{l}1.056^{* * *} \\
(0.309)\end{array}$ & $\begin{array}{l}0.857^{* *} \\
(0.293)\end{array}$ \\
\hline Observations & 488 & 966 & 1,102 & 1,616 & 1,706 & 1,774 \\
\hline$-2 \mathrm{LL}$ & 423.188 & 673.645 & 959.770 & 861.893 & $1,088.999$ & $1,279.450$ \\
\hline Nagelkerke $R^{2}$ & 0.540 & 0.664 & 0.537 & 0.765 & 0.702 & 0.648 \\
\hline
\end{tabular}

Notes: ${ }^{* * *} \mathrm{p}<0.01,{ }^{* *} \mathrm{p}<0.05$. Variable coefficients are presented in the first row, while standard errors are presented in the second row in parentheses.

Table 4: Bankruptcy and rescue plan models

Estimated rescue plan models (when compared with bankruptcy prediction models) resulted in similar findings for ROA, ATURN, SOL and AGE variables. All these variables had negative and statistically significant signs, which is in line with theoretical expectations. However, one significant difference was related to the SIZE variable, which in the case of rescue plan models was positive, indicating that larger firms were more likely to enter into the rescue plan procedure. This finding may be a reflection of the stakeholders' expectation that larger failed firms would perform better by restructuring in comparison with smaller firms. Also, in many cases the government was one of the largest creditors because of the large amounts of unsettled obligations for taxes and other duties for government-controlled funds (health care and pension funds). In such situations, due to potential political costs (strikes, union pressure, etc.), the government was probably more likely to accept a rescue plan aiming to protect working places in larger firms as opposite to smaller firms. Another difference between bankruptcy and rescue plan models was observable regarding the liquidity variable CUR, which was negative and significant for the $\mathrm{t}-1$ and $\mathrm{t}-2$ lags. When rescue plan models were estimated for only for non-micro firms, the signs of all variables were identical to those of the total sample model, while the only difference occurred with the CUR variable, which in this specification was insignificant. The overall fit of estimated rescue prediction models was little higher than for bankruptcy models since the pseudo $R^{2}$ measure, Nagelkerke $R^{2}$, was in the range between $0.648(\mathrm{t}-3)$ and $0.765(\mathrm{t}-1)$. The rescue plan model for the total sample had the lowest overall error of $11.5 \%$ for the t-1 lag, while the overall error increased with time lags (13.7\% for t-2 and $15.3 \%$ for $\mathrm{t}-3)$. Similar findings were observable for Type I error, since this error was $11.8 \%(\mathrm{t}-1), 14.5 \%(\mathrm{t}-2)$ and $15.3 \%(\mathrm{t}-3)$. The estimation of rescue plan model for only non-micro firms increased prediction accuracy since the overall error dropped to $8.8 \%(\mathrm{t}-1), 12.5 \%(\mathrm{t}-2)$ and $11.4 \%(\mathrm{t}-3)$. Similarly, Type I error for non-micro firm estimation decreased to $8.4 \%(\mathrm{t}-1), 12.5 \%(\mathrm{t}-2)$ and $9.8 \%(\mathrm{t}-3)$. 


\begin{tabular}{|c|c|c|c|c|c|c|}
\hline \multirow[t]{2}{*}{ Variable } & \multicolumn{3}{|c|}{$\begin{array}{l}\text { Financial distress models - } \\
\text { total sample }\end{array}$} & \multicolumn{3}{|c|}{$\begin{array}{l}\text { Financial distress models - } \\
\text { non-micro firms }\end{array}$} \\
\hline & Model $_{\mathrm{t}-1}$ & Model $_{\mathrm{t}-2}$ & Model $_{t-3}$ & Model $_{\mathrm{t}-1}$ & Model $t_{t-2}$ & Model $_{\mathrm{t}-3}$ \\
\hline ROA & $\begin{array}{l}-0.131^{* * *} \\
(0.010)\end{array}$ & $\begin{array}{l}-0.103^{* * *} \\
(0.008)\end{array}$ & $\begin{array}{l}0.004 \\
(0.003)\end{array}$ & $\begin{array}{l}-0.063 \\
(0.092)\end{array}$ & $\begin{array}{l}-0.168 \\
(0.136)\end{array}$ & $\begin{array}{l}-0.071^{* *} \\
(0.028)\end{array}$ \\
\hline EBITM & $\begin{array}{l}-0.134^{* * *} \\
(0.011)\end{array}$ & $\begin{array}{l}-0.130^{* *} \\
(0.010)\end{array}$ & $\begin{array}{l}-0.055^{* * *} \\
(0.004)\end{array}$ & $\begin{array}{l}-0.658^{* * *} \\
(0.173)\end{array}$ & $\begin{array}{l}-0.522^{* *} \\
(0.176)\end{array}$ & $\begin{array}{l}-0.070^{* * *} \\
(0.019)\end{array}$ \\
\hline ATURN & $\begin{array}{l}-0.053^{* *} \\
(0.022)\end{array}$ & $\begin{array}{l}-0.050^{* * *} \\
(0.022)\end{array}$ & $\begin{array}{l}-0.041^{* * *} \\
(0.007)\end{array}$ & $\begin{array}{l}-0.112 \\
(0.174)\end{array}$ & $\begin{array}{l}-0.242 \\
(0.193)\end{array}$ & $\begin{array}{l}-0.070 \\
(0.060)\end{array}$ \\
\hline CUR & $\begin{array}{l}0.041 \\
(0.038)\end{array}$ & $\begin{array}{l}0.084^{* *} \\
(0.043)\end{array}$ & $\begin{array}{l}0.039^{* *} \\
(0.015)\end{array}$ & $\begin{array}{l}-0.216 \\
(0.316)\end{array}$ & $\begin{array}{l}-0.361) \\
(0.257)\end{array}$ & $\begin{array}{l}0.050 \\
(0.070)\end{array}$ \\
\hline $\mathrm{SOL}$ & $\begin{array}{l}-0.037^{* * *} \\
(0.002)\end{array}$ & $\begin{array}{l}-0.038^{* * *} \\
(0.003)\end{array}$ & $\begin{array}{l}-0.037^{* * *} \\
(0.002)\end{array}$ & $\begin{array}{l}-0.046^{* *} \\
(0.022)\end{array}$ & $\begin{array}{l}-0.028^{* *} \\
(0.014)\end{array}$ & $\begin{array}{l}-0.036^{* * *} \\
(0.007)\end{array}$ \\
\hline $\mathrm{AGE}$ & $\begin{array}{l}0.007 \\
(0.006)\end{array}$ & $\begin{array}{l}0.004 \\
(0.005)\end{array}$ & $\begin{array}{r}-0.0001 \\
(0.003)\end{array}$ & $\begin{array}{l}0.023 \\
(0.022)\end{array}$ & $\begin{array}{l}0.003 \\
(0.023)\end{array}$ & $\begin{array}{l}0.008 \\
(0.010)\end{array}$ \\
\hline SIZE & $\begin{array}{l}0.296^{* * *} \\
(0.036)\end{array}$ & $\begin{array}{l}0.231^{* * *} \\
(0.031)\end{array}$ & $\begin{array}{l}-0.038^{* *} \\
(0.018)\end{array}$ & $\begin{array}{l}-0.914^{* *} \\
(0.422)\end{array}$ & $\begin{array}{l}-0.352 \\
(0.363)\end{array}$ & $\begin{array}{l}-0.231 \\
(0.149)\end{array}$ \\
\hline Constant & $\begin{array}{l}-1.448^{* * *} \\
(0.259)\end{array}$ & $\begin{array}{l}-1.029^{* * *} \\
(0.248)\end{array}$ & $\begin{array}{l}1.718^{* * *} \\
(0.128)\end{array}$ & $\begin{array}{l}8.769^{* *} \\
(4.082)\end{array}$ & $\begin{array}{l}3.415 \\
(3.412)\end{array}$ & $\begin{array}{l}3.413^{* *} \\
(1.360)\end{array}$ \\
\hline Observations & 6,400 & 6,484 & 6,066 & 348 & 376 & 366 \\
\hline$-2 \mathrm{LL}$ & $1,828.721$ & $2,193.148$ & $5,671.801$ & 48.817 & 52.206 & 287.086 \\
\hline Nagelkerke $R^{2}$ & 0.890 & 0.866 & 0.484 & 0.950 & 0.950 & 0.603 \\
\hline
\end{tabular}

Notes: ${ }^{* * *} \mathrm{p}<0.01,{ }^{* *} \mathrm{p}<0.05$. Variable coefficients are presented in the first row, while standard errors are presented in the second row in parentheses.

Table 5: Financial distress models

Since model estimations for bankruptcy and rescue plans have shown that separated estimations for non-micro firms result in increased predictive power, table 5 presents both specifications (for the total sample and for non-micro firms) of proposed distress prediction models. The overall fit of estimated financial distress models was higher than for legal failure definition models, as pseudo $\mathrm{R}^{2}$, Nagelkerke $\mathrm{R}^{2}$, was in the range between $0.866(\mathrm{t}-2)$ and $0.890(\mathrm{t}-1)$ for the whole sample. The estimation only for nonmicro firms resulted in an even higher fit $(0.950)$ for the first two lags.

The EBITM and SOL variables in financial distress models were significant in both size specifications and in all time lags with negative signs, indicating that increased profitability and selffinancing reduces the likelihood of financial distress. ATURN, as expected, had a negative sign, but it was significant only for the total sample models. The CUR variable was positive for the total sample specification, yet insignificant for non-micro firms. Results on AGE were stable and the variable was insignificant in all specifications, while results on SIZE were mixed. For the total sample, the SIZE variable was significant and positive in $\mathrm{t}-1$ and $\mathrm{t}-2$, indicating that larger firms were more likely to be financially distressed. However, when micro firms were removed from the estimation, SIZE became negative in all periods, but significant only in t-1. Industry dummies were not statistically significant in any of the observed models and therefore were excluded from further consideration.

Financial distress models for the whole sample had the lowest overall error and Type I error when compared with bankruptcy and rescue plan models. Namely, financial distress models for the total sample in period t- 1 resulted in an overall error of $4.7 \%$ in comparison with $20.7 \%$ (bankruptcy model) and $11.5 \%$ (rescue plan model). The statistical significance of differences in calculated error proportions were tested with the z-test, and the conclusion was that the overall error of the financial distress model was 
significantly lower in comparison with the bankruptcy model $(\mathrm{z}=10.27 ; \mathrm{p}<0.01)$ and the rescue plan model $(\mathrm{z}=6.75 ; \mathrm{p}<0.01)$. In the case of the total sample in time $\mathrm{t}-1$, the financial distress model had Type I error of $5.6 \%$, while this type of error was much higher for the bankruptcy model $(22.5 \%)$ and the rescue plan model (11.8\%). All differences in Type I error proportions were tested with the z-test and found to be significant at the $1 \%$ level. In order to check whether the higher hit rate of the financial distress model might be related to the sample size, which was larger in comparison with the samples used for the estimation of the two alternative models, we conducted an additional analysis. Namely, we randomly selected a subsample of only 488 observations, which was the sample size used for the bankruptcy model. Such a financial distress model resulted in slightly increased model errors, while differences in error proportions in comparison with legal status models remained significant at the $1 \%$ level. Here we can conclude that the higher hit rate of the financial distress model is caused by variables in the model, while the sample size did not significantly influence model accuracy. When the model was estimated for non-micro firms with a t- 1 lag, the overall errors and Type I errors were the lowest for the distress model $(4.6 \%$ and $5.5 \%)$, while the bankruptcy model (5.4\% and $5.9 \%)$ and the rescue plan model $(8.8 \%$ and $8.4 \%)$ resulted in higher errors. Calculated differences in error proportions were tested with the z-test, which resulted in finding that error in the financial distress model was significantly lower in comparison with the rescue plan model $(\mathrm{z}=4.7 ; \mathrm{p}<0.01)$, while it was not significantly lower in comparison with the bankruptcy model $(\mathrm{z}=0.26, \mathrm{p}=0.56)$.

On the basis of previously presented analysis of alternative failure prediction models it is possible to draw several conclusions. Firstly, accounting information and financial ratios can be effectively used for firm failure prediction. Estimated financial ratios signs are theoretically justifiable and comparable with similar previous studies. In general, findings confirmed that with time lags, information quality of accounting data for failure prediction is deteriorating. Proposed financial distress model has shown the highest model fit measured by Nagelkerke $\mathrm{R}^{2}$, when compared with bankruptcy and rescue plan models. Similarly, financial distress model for the whole sample outperformed traditional failure models in terms of overall prediction error and Type I error. In the case of non-micro firms, errors in the financial distress model were the lowest, but significantly lower only in comparison with the rescue plan model. The vast majority of estimated coefficients had stable signs in different specifications, while the separated estimation of models for nonmicro firms has shown good effects in terms of obtaining theoretically expected variable signs, as well as in terms of reduced prediction errors.

\section{Concluding remarks}

In order to develop a failure prediction model suitable for the Croatian business environment, we proposed the financial distress model and confronted it with the traditional legal status failure models. For the purpose of our research, a firm is characterised as being financially distressed when its EBITDA is lower than its interest expenses for two consecutive periods. Empirical findings were based on a large and representative set of observations of Croatian firms from different industries and with different sizes. The proposed financial distress model for the whole sample outperformed traditional failure models in terms of model fit as well as in the overall prediction error and Type I error. In the case of non-micro firms, errors in the financial distress model were significantly lower in comparison with the rescue plan model, while in comparison with the bankruptcy model errors were lower, but insignificantly. Analysis of time lags of accounting information has confirmed its high deterioration in the context of firm failure prediction. Additional analysis revealed that it is useful to develop a separated failure model for non-micro firms because separate estimations result in improved prediction power in comparison with models built generically for the overall firm population. A developed financial distress model can be practically applied by investors and creditors since it is based on publicly available information from a firm's annual reports. 
With the application of the financial distress model, decision makers can timely evaluate firm failure risks and undertake required business decisions (selling investments, suspending additional lending, legal actions, etc.) before a firm enters the terminal stage. Future research in the field of failure prediction may use data for longer periods with the application of panel data estimators. Additional contributions to the literature could be obtained by conducting a cross country analysis and by comparing the financial distress model with traditional models in international settings.

\section{Acknowledgement}

This work has been fully supported by Croatian Science Foundation under the project UIP-2014-09-1745. Any opinions, findings, and conclusions or recommendations expressed in this material are those of the authors and do not necessarily reflect the views of Croatian Science Foundation.

\section{References}

[1] Altman, E. I. (1968). Financial ratios, discriminant analysis and the prediction of corporate bankruptcy. Journal of Finance, 23 (4), 889-607.

[2] Altman, E. I. and Sabato, G. (2007). Modeling Credit Risk for SMEs: Evidence from U.S. Market. Abacus, 43 (3), 332-357.

[3] Altman, E. I., Iwanicz-Drozdowska, M., Laitinen, E. and Suvas A. (2017). Financial Distress Prediction in an International Context: A Review and Empirical Analysis of Altman's Z-Score Model. Journal of International Financial Management \& Accounting, 28 (2), 131-171.

[4] Agarwal, V. and Taffler, R. (2007). Twenty-five years of the Taffler z-score model: does it really have predictive ability?. Accounting and Business Research, 37 (4), 285-300.

[5] Bain, J. (1951). Relation of Profit Rate to Industry Concentration: American Manufacturing, 19361940. Quarterly Journal of Economics, 65, 293-324.

[6] Balcaen, S., and Ooeghe, H. (2006). 35 years of studies on business failure: on overview of the classic statistical methodologies and their related problems. The British Accounting Review, 38 (1), 63-93.

[7] Baumol, W. J. (1959). Business Behaviour, Value and Growth. New York: Macmillan.

[8] Beaver, W. (1967). Financial ratios as predictor of failure, empirical research in accounting: selected studies 1966. Journal of Accounting Research, 4, 71-111.

[9] Cultrera, L. and Bredart, X. (2016). Bankruptcy prediction: the case of Belgian SMEs. Review of Accounting and Finance, 15 (1), 101-119.

[10] Deakin, E. B. (1972). A Discriminant Analysis of Predictors of Business Failure. Journal of Accounting Research, 10 (1), pp.167-179.

[11] Hair, J. F., Black, W. C., Babin, B. J. and Anderson, R. E. (2010). Multivariate Data Analysis, Harlow, UK: Pearson Prentice Hall.

[12] HGK (2018). Gospodarska kretanja, (3/4), 22-23.

[13] Majumdar, S. K. (1997). The Impact of Size and Age on Firm-Level Performance: Some Evidence from India. Review of Industrial Organization, 12, 231-241.

[14] Mirzaei, M., Ramakrishnan, S. and Bekri, M. (2016). Corporate default prediction with industry effects: Evidence from emerging markets. International journal of economics and financial issue, 6 (3) 161-169.

[15] Mramor, D. and Valentincic, A. (2003). Forecasting liquidity of very small private companies. Journal of Business Venturing, 13, 745-771. 
[16] Nam, J-H. and Jinn, T. (2000), Bankruptcy prediction: Evidence from Korean Listed Companies During the IMF Crisis. Journal of International Financial Management and Accounting, 11 (3), 178197.

[17] Ohlson, J. A. (1980). Financial ratios and the probabilistic prediction of bankruptcy. Journal of Accounting Research, 18 (1), 109-131.

[18] Pervan, I., and Kuvek, T. (2013). The relative importance of financial ratios and nonfinancial variables in predicting of insolvency. Croatian Operational Research Review, 13 (4), 187-197.

[19] Pindado, J. and Rodrigues, L. F. (2004). Parsimonious models of financial insolvency in small companies. Small Business Economics, 22, 51-66.

[20] Pindado, J., Rodrigues, L. F. and de la Torre, C. (2008). Estimating financial distress likelihood, Journal of Business Research, 61 (9), 995-1003.

[21] Platt, H., D. and Platt., M., B. (2002): Predicting Corporate Financial Distress: reflections on Choice-Based Sample Bias. Journal of Economics and Finance, 26 (2), 184-99.

[22] Rezende, F., Montezano, S., Marcos, R. and Oliveira, N. (2017). Predicting financial distress in publicly-traded companies, Revista Contabilidade \& Financas, 28 (75), 390-406.

[23] Sajter, D. (2010). Procedura i praksa restrukturiranja u stečaju u Republici Hrvatskoj (Procedure and practice of restructuring in bankruptcy in Croatia), Zbornik radova Pravnog fakulteta u Splitu, 47 (3), 729-744.

[24] Smith, M. and Liou, D. (2007). Industrial sector and financial distress. Managerial Auditing Journal, 22, 376-391.

[25] Šarlija, N., Penavin, S. and Harc, M. (2009). Predviđanje nelikvidnosti poduzeća u Hrvatskoj (Firm insolvency prediction in Croatia). Zbornik Ekonomskog fakulteta u Zagrebu, 2, 21-36.

[26] Tomas Žiković, I. (2018). Challenges in Predicting Financial Distress in Emerging Economies: The Case of Croatia, Eastern European Economics, 56 (1), 1-27.

[27] Vuran, B. (2009). Prediction of business failure: a comparison of discriminant and logistic regression analyses. Istanbul University Journal of the School of Business Administration, 38 (1), 47-65.

[28] Williamson, O. E. (1985). The Economic Institutions of Capitalism. New York: Free Press.

[29] Zenzerović, R. (2009). Business financial problem prediction-Croatian experience, Ekonomska istraživanja, 22 (4), 1-16. 